\title{
Progress in Tertiary Content-Based ESL Instruction
}

Rebecca L. Oxford

Content-based ESL aims to develop communicative competence in the target language along with content knowledge in a specific subject area, such as mathematics. Many forms of CB-ESL are discussed here. English for specific purposes (including but not limited to English for acadenic purposes) is a very well known type. Other versions-some popular and others less well known-are theme-based, task-based, adjunct, and sheltered CB-ESL. This article analyzes tertiary (post-secondary) students' language needs; indicates how CB-ESL treats those needs; highlights key CBESL issues in math, social studies, and sciences; and offers implications for instruction and research.

\section{INTRODUCTION}

Language skill integration involves linking the four language skills of listening, reading, speaking, and writing with the intent of emphasizing real, meaningful communication. A prevalent form of ESL skill integration at the tertiary level (college, junior college, community college, technical or vocational school, or university, generally called the "postsecondary" level in North America) is content-based ESL, or CB$E S L$. In CB-ESL, the primary goal is communicative competence in the target language, and an associated aim is content knowledge, such as mathematics, sociology, or science (Brinton, Snow, \& Wesche, 1989; Cantoni-Harvey, 1987; Mohan, 1986, 1990; Richards \& Hurley, 1990; Scarcella \& Oxford, 1992; Secada \& Carey, 1990; Snow, Met, \& Genesee, 1989; Spanos, 1989; Short, Crandall, \& Christian, 1989). The trend toward tertiary CB-ESL instruction parallels cross-curriculum tertiary-level movements for native English speakers, such as "writing across the curriculum," "reading to write," and "writing to read." It also parallels the tertiary foreign language format of immersion, either partial or total. In all of these, the concern is for meaningful content to be taught in the target language at the same time as language skills are developed.

This article chronicles the growth of tertiary CB-ESL instruction especially in Canada, the U.S., and the U.K., where this phenomenon has been making remarkable progress in the last two decades. First, we analyze tertiary students' language needs and show how these are handled by CB-ESL. Second, we describe several main approaches and methods involving tertiary CB-ESL. Next, we highlight specific issues in the teaching of tertiary CB-ESL in three subject areas: 
mathematics, social studies, and science. Finally, using the previous topics as a springboard, we provide instructional implications and cite key research questions to be addressed in the future.

\section{LANGUAGE NEEDS OF TERTIARY ESL STUDENTS}

What language needs must tertiary ESL students fulfill in order to do well in their studies and their personal interactions? The answers can be obtained by considering different modes of language, such as social and academic.

\section{Social vs. Academic Language Needs}

Collier (1989), whose primary research is with K-12 students, nevertheless has produced recommendations that relate well to tertiary students. Collier recommends that content-based, integrated-skill academic instruction should occur while ESL students are mastering basic, social language skills. This relates to earlier research by Cummins $(1979,1981)$ on the important distinctions between basic interpersonal communication skills (BICS) and cognitive academic language proficiency (CALP)-or, more simply, between social vs. academic language abilities.

As suggested by Cummins (1981, 1984), the language used for academic tasks is often very different from the language used for basic social exchanges. Cummins (1984) has described language proficiency in terms of two continua: (a) cognitive difficulty of the task and (b) amount of context in which language occurs. Difficulty of the task ranges from cognitively undemanding, as in learning definitions and reading road signs, to cognitively demanding, as in making an oral presentation on an academic or technical topic. Context for language can be very rich (what Cummins calls embedded), that is, full of linguistic or extralinguistic clues (situational noise, gestures, social status of interlocutors) to the meaning. Alternatively, context can be reduced, that is, missing such additional clues to meaning.

Compared with basic interpersonal communication tasks, cognitive academic tasks are often more intellectually demanding and more context-reduced, with meaning typically inferred from linguistic or literacy-related features of a relatively formal written or oral text. This is the most difficult situation for language learners, and competence in these types of tasks frequently occurs later than competence in basic interpersonal communication tasks. Many basic interpersonal communication tasks are cognitively less demanding and more contextembedded, with plenty of situational clues to the meaning. This is the easiest circumstance for language learners, and competence in these kinds of tasks occurs earlier than competence in many cognitive 
academic tasks. Learners need to cope with both these difficult and easy tasks, as well as the ones in between (tasks that are cognitively demanding and context-embedded, and tasks that are cognitively undemanding and context-reduced).

Compared with social language, academic language is thus much more difficult and is later in developing to a proficient level. Cummins (1982) uses Canadian research to indicate that ESL learners can develop proficiency in social language within two years, whereas success with academic language at the level of native English speakers ordinarily takes five to seven years (see King, Fagan, Bratt, \& Baer, 1987 for additional comments). Thus, there might be a time gap between the period when ESL learners can function well with the social aspects of the English and the stage when they can function effectively with academic aspects of English in a regular course. Part of the determination of the time lag depends on how well students have already developed academic language ability in their own native language.

Cummins (1979) theorizes that it is especially important to achieve some level of capability in academic communication in the person's native language first. Once a certain minimal academic language proficiency threshold has been reached in the first language, this can easily be transferred to a second language. Cummins warns that if the threshold has not been reached in the first language, i.e., if students are mainstreamed too soon into regular academic classes without any assistance, it is difficult or impossible to develop academic language ability through the second language. Put differently, if the student cannot use words, phrases, and concepts for academic purposes in the first language, he or she will not be able to do it in ESL.

Snow, Met, and Genesee (1989) studied language needs of ESL students in terms of content-obligatory language, i.e., language essential to understanding content, and content-compatible language, i.e., language which pairs quite naturally within a given concept or content area. In some types of CB-ESL (as in English for special purposes, where technical language is often demanded), contentobligatory language is used, whereas in other types of CB-ESL, there is more flexibility and content-compatible language is acceptable.

\section{Pursuing the Academic: Surveys of Academic Language Needs}

Numerous investigations have been conducted that provide clear delineation of the types of language skills required for tertiary ESL students to succeed academically (e.g., Kroll, 1979; Ostler, 1980; Johns, 1981; Bridgeman \& Carlson, 1983; Santos, 1988; Spack, 1988). Snow and Brinton (1991), summarizing these studies, state that (a) an 
English for academic purposes (EAP) program should emphasize all the skill areas, including listening and speaking, and not just writing, which has tended to receive the most attention; and (b) ESL students require experience with "academic information processing," i.e., understanding real content presented in a conventional academic context. Thus, content-based learning is an important requirement for tertiary ESL students.

"Academic information processing" can include any of the higherlevel thinking skills noted by Bloom in his taxonomy of cognitive processes: application, analysis, synthesis, and evaluation. Unfortunately, some academic situations involve lower-level thinking skills that appear at the bottom of Bloom's taxonomy, such as simple knowledge (recall and recognition-also commonly known among university students as "regurgitation" on tests) and comprehension without any further application or investigation.

In a model of second language learning, Chamot (1983) divided the higher-level and lower-level thinking skills using Bloom's taxonomic stages, with the higher four known as academic proficiency and the lower two related to social proficiency. Thus, although many academic situations demand lower-level thinking skills, Chamot does not deem them worthy of the academic label. In her model, Chamot linked all the thinking skills with the linguistic requirements necessary for exercising such skills. Language skills and thinking skills can be developed simultaneously in content-based classes, as shown by the CALLA instructional model developed by O'Malley and Chamot (most recently explained in their 1991 book).

Responding to many of these needs, particularly in the area of academic language skills, researchers and practitioners have experimented with creative approaches and methods for tertiary CB-ESL. We now examine the evidence regarding these approaches and methods.

\section{APPROACHES AND METHODS ASSOCIATED WITH TERTIARY CONTENT-BASED INSTRUCTION}

Five approaches and methods related to content-based instruction at the tertiary level are discussed below: Note that two of these (theme-based and task-based) were not necessarily designed for tertiary instruction and are actually used at many educational levels, whereas the other three were developed primarily with tertiary students in mind:

- English for specific purposes (ESP), in which the language skills are integrated for the purpose of learning English to be used in particular situations for specific needs (e.g., English for academic purposes, 
English for science and technology; see Hutchinson \& Waters, 1987; Swales, 1985).

- theme-based $C B-E S L$, in which the language skills are integrated in the study of a theme, e.g., global warming (Brinton, Snow, \& Wesche, 1989);

- task-based $C B$-ESL, in which language skills are integrated through meaningful language tasks that can be, but are not necessarily, related to a specific body of content (Scarcella \& Oxford, 1992).

- adjunct CB-ESL, in which separate language and content courses are linked through the coordination of the instructors and the curricula (Snow \& Brinton, 1988);

- sheltered $C B-E S L$, in which learners are taught the subject matter and the language using simplified English that is modified to the students' level of proficiency (Edwards, Wesche, Krashen, Clément, \& Kruidenier, 1984).

These are not all equivalent in scope, generality, or intent. Some are specific methods (e.g., sheltered CB-ESL and adjunct CB-ESL), while others are broader approaches (such as ESP, task-based ESL, and theme-based ESL). See Richards and Rodgers (1986) for the differences between general approaches and specific methods.

Table 1 summarizes the characteristics of these five approaches and methods according to the following criteria: approach vs. method; how language and content are integrated; target proficiency levels; typical students; basis of course structure; and context reduced or embedded. Cognitive demands are not included as a descriptor in Table 1 , because we can assume that at the tertiary level such demands will be high in all approaches and methods.

\section{English for Specific Purposes (ESP)}

ESP selects and teaches language material for chosen settings: medicine, engineering, commerce, hotel management, science, and so on. According to Hutchinson and Waters (1987), ESP is not just a matter of teaching specialized varieties of English; commonalities are greater than differences across ESP courses, although certain features of the language are typical of a given context or field. Moreover, there is no single ESP methodology, but rather there are good language teaching methodologies that are applied in the ESP situation. Thus, ESP is a general approach rather than a specific methodology. In the ESP perspective, the language teacher does not need to master the subject matter but should accept the status of an interested co-student of the subject matter; this prevents the teacher from becoming overwhelmed by technical content. ESP teachers should let students know initially that they (the teachers) are not experts in the subject 
area, so that students will not be surprised when they discover this. (Of course, subject area experts, such as hotel management specialists, can become ESP teachers through a teacher education program, but in practice this rarely is the case.)

\section{TABLE 1}

\section{Characteristics of Five Types of CB-ESL}

\begin{tabular}{|c|c|c|c|c|c|c|}
\hline Name & $\begin{array}{l}\mathrm{A} \\
\text { or } \\
\mathrm{M}\end{array}$ & $\begin{array}{l}\text { How Language } \\
\text { and Content } \\
\text { are Integrated }\end{array}$ & $\begin{array}{l}\text { Target } \\
\text { Proficiency } \\
\text { Levels }\end{array}$ & $\begin{array}{l}\text { Typical } \\
\text { Students }\end{array}$ & $\begin{array}{l}\text { Basis of } \\
\text { Course } \\
\text { Structure }\end{array}$ & $\begin{array}{l}\text { Context } \\
\text { Reduced or } \\
\text { Embedded }\end{array}$ \\
\hline $\begin{array}{l}\text { English } \\
\text { for } \\
\text { specitic } \\
\text { purposes }\end{array}$ & $A$ & $\begin{array}{l}\mathrm{L} \text { and } \mathrm{C} \text { are } \\
\text { integrated for } \\
\text { use in specific } \\
\text { contexts }\end{array}$ & $\begin{array}{l}\text { Int. to } \\
\text { adv. }\end{array}$ & $\begin{array}{l}\text { NNS with } \\
\text { same goals; } \\
\text { usually } \\
\text { adults }\end{array}$ & $\begin{array}{l}\text { Functional } \\
\text { needs for } \\
\text { specific } \\
\text { needs }\end{array}$ & $\begin{array}{l}\text { Varies, often } \\
\text { context } \\
\text { embedded due } \\
\text { to content \& } \\
\text { simitar back- } \\
\text { grounds/ needs } \\
\text { of participants }\end{array}$ \\
\hline $\begin{array}{l}\text { Theme- } \\
\text { based }\end{array}$ & A & $\begin{array}{l}\mathrm{L} \text { and } \mathrm{C} \text { are } \\
\text { integrated in } \\
\text { the study of a } \\
\text { theme }\end{array}$ & All & $\begin{array}{l}\text { All ages of } \\
\text { NNS, esp. } \\
\text { those who } \\
\text { share at least } \\
\text { some inter- } \\
\text { ests }\end{array}$ & $\begin{array}{l}\text { Themes of } \\
\text { higl general } \\
\text { interest to } \\
\text { most people } \\
\text { (e.g., sex } \\
\text { roles) }\end{array}$ & $\begin{array}{l}\text { Varies, can be } \\
\text { context } \\
\text { embedded due } \\
\text { to richness of } \\
\text { thematic clues } \\
\text { to meaning }\end{array}$ \\
\hline Task-based & A & $\begin{array}{l}\text { L skills are } \\
\text { used to carry } \\
\text { out tasks. } \\
\text { which involve } \\
\text { C }\end{array}$ & All & $\begin{array}{l}\text { All ages of } \\
\text { NNS, esp. } \\
\text { those willing } \\
\text { to be per- } \\
\text { sonally in- } \\
\text { volved in } \\
\text { real language } \\
\text { tasks }\end{array}$ & $\begin{array}{l}\text { Motivating } \\
\text { tasks in- } \\
\text { volving } \\
\text { interaction; } \\
\text { can be aca- } \\
\text { demic or } \\
\text { social tasks }\end{array}$ & $\begin{array}{l}\text { Varies, often } \\
\text { context } \\
\text { embedded } \\
\text { because of } \\
\text { clues in the } \\
\text { tasks }\end{array}$ \\
\hline Adjunct & $\mathbf{M}$ & $\begin{array}{l}\text { Separate } L \text { and } \\
C \text { courses are } \\
\text { linked through } \\
\text { coordination of } \\
\text { insiructors and } \\
\text { curriculum }\end{array}$ & $\begin{array}{l}\text { High int. to } \\
\text { adv. }\end{array}$ & $\begin{array}{l}\text { NNS of all } \\
\text { ages in same } \\
\text { academic or } \\
\text { vocational } \\
\text { program as } \\
\text { NS }\end{array}$ & $\begin{array}{l}\text { ESL and } \\
\text { content } \\
\text { teachers } \\
\text { working } \\
\text { together }\end{array}$ & $\begin{array}{l}\text { Varies, often } \\
\text { context } \\
\text { reduced due to } \\
\text { academic level } \\
\text { and subject } \\
\text { area }\end{array}$ \\
\hline Shellered & $M$ & $\begin{array}{l}\mathrm{C} \text { is taught } \\
\text { using simplified } \\
\mathrm{L}\end{array}$ & Int. & $\begin{array}{l}\text { All ages of } \\
\text { NNS. esp. } \\
\text { adults highly } \\
\text { motivated } \\
\text { academically } \\
\text { or voca- } \\
\text { tionally }\end{array}$ & $\begin{array}{l}\text { Subject } \\
\text { matter sim- } \\
\text { plified in } \\
\text { language } \\
\text { but not } \\
\text { necessatily } \\
\text { in concepts }\end{array}$ & $\begin{array}{l}\text { Varies, often } \\
\text { context } \\
\text { reduced due to } \\
\text { academic level } \\
\text { and subject } \\
\text { area }\end{array}$ \\
\hline
\end{tabular}

KEY: NNS $=$ non-native speaker $\quad$ NS $=$ native speaker $\quad$ Int. $=$ intermediate $\quad A d v,=$ advanced $\mathrm{L}=$ language $\mathrm{C}=$ content $\mathrm{A}=$ Approach $\mathrm{M}=$ Method

Brinton, Snow, and Wesche (1989) describe ESP as part of the larger movement concerning language for specific purposes (LSP), which these authors state is possible only when the characteristics, 
needs, and purposes of a group of students are relatively homogeneous. The unifying nature is that the objectives and language content of each course are defined according to the learners' functional requirements in the new langunge in a specific context, which is often occupational but might instead be English for academic purposes (EAP). Context is often embedded because of because of similar backgrounds and needs of participants; however, if a person from a different environment or set of interests became involved, the context for that person would naturally be reduced.

Mohan (1986) notes that ESP is similar in approach to reading in the content areas and that the historical development of ESP has paralleled that of cross-content reading skills. In almost every instance since its inception in the late 1960s in England, ESP has been a content-focused instructional phenomenon for highly motivated adults. ESP is a response to the expansion of technology and commerce throughout the world in the 1960s-although ESP can also be used for other age groups. This expansion created a vast cadre of adult learners who needed and wanted language in a whole range of specialty areas, including medicine, business, finance, and engineering. The oil crises of the early 1970s resulted in a massive flow of funds and western expertise into the Middle East, where ESP suddenly became a commercial necessity for many non-English speakers (Hutchinson \& Waters, 1987). Now many countries throughout the world have programs in ESP. As ESP developed, emphasis rapidly became fixed on the content material and then on the content learning task (e.g., description, generalization, classification, hypothesis creation), supposedly transferrable to other content areas.

English for science and technology (EST) was the first area of ESP to be developed, and EST and ESP were for a time treated as synonyms. Later came English for business and economics (EBE), and English for social sciences (ESS). Each of these can be divided into two branches: EAP as noted above, e.g., English for medical studies, English for economics, and English for psychology; and English for occupational purposes (EOP), also known as vocational ESL (VESL), e.g., English for technicians, English for secretaries, and English for teaching (Hutchinson \& Waters, 1987). Perhaps these labelsespecially the categories listed under EAP and EOP-are of the hairsplitting variety, but they find their way regularly into journal articles and books about content-based language learning at the tertiary level.

ESP is one of the most significant movements in English language teaching today. It is regularly used in many countries by industrial and business companies, hospitals, and other sectors and has found its way into universities and technical schools. 


\section{Theme-Based CB-ESL}

The approach known as theme-based CB-ESL integrates the language skills through the study of a particular aspect of content known as a "theme," such as the environment, careers, foods, or family customs. Sometimes a course covers just one major theme, but at other times a course includes up to a dozen different themes. Themebased instruction is widespread in ESL and is moving into a variety of foreign languages such as Spanish and French. According to Brinton, Snow, and Wesche (1989), theme-based instruction is useful at all ages, but it lends itself especially well to heterogeneous groups of adult learners who share some common areas of interest. Theme-based instruction is useful with all proficiency levels. Educational and cultural background is important in selecting the themes because of the obvious factor of motivation and interest. Theme-based instruction can be context embedded because of the richness of thematic clues to meaning.

Brinton, Snow, and Wesche (1989) note many studies of ESL programs using theme-based instruction. For instance, Reid (1984) described theme-based ESL courses at the WESL Institute of Western Illinois University in the U.S. Topics ranged widely from genetic engineering to Native American culture. Fein and Baldwin (1986) discussed the theme-based, integrated-skill ESL curriculum for advanced students in the daytime intensive program of the University of California at Los Angeles (UCLA) American Language Center. Eskey, Kraft, and Alvin (1984) described theme-based ESL courses at the University of Southern California, noting success in fluency development but heavy burdens on teachers for materials and curriculum development. Other theme-based ESL programs cited by Brinton, Snow, and Wesche include the Monterey Institute, the University of Nevada at Reno, Southern Illinois University, Carleton University, and the Free University of Berlin.

Brinton, Snow, and Wesche also provide extensive detail on the evening intensive ESL program at the UCLA American Language Center. Both credit and noncredit courses are offered to students who are upwardly mobile professionals desiring better English skills. ALC theme-based courses vary from quarter to quarter but typically consist of three to four large themes (e.g., sex roles, gun control, computer crime) or a single very large theme (e.g., environmental concerns) broken into related subunits. Extensive use is made of multimedia in all thematic courses in the program.

Lafayette and Buscaglia (1985) report on a study of a fourthsemester theme-based course in French civilization which was conducted in French at Indiana University in the U.S. Comparison with students enrolled in a regular fourth-semester section revealed 
that the students in the content course made significant gains in listening, speaking, and writing; students in the traditional course made significant gains in listening and writing. In addition, the experimental (theme-based) group reported more positive attitudes toward the study of French.

Giauque (1987) described a theme-based French course in Greek mythology for third-year university students at Northern Arizona University in the U.S. In this course, students read authentic texts, listened to lectures and took notes in French, participated in discussions, and wrote papers and exams in French, and they were rewarded with general education credit in the humanities and in the language.

\section{Task-Based Instruction}

Yet another approach for uniting the language skills at the tertiary level is task-based ESL instruction. Task-based instruction is an integrated approach to language program design (Long, 1985). This approach has as its main focus "tasks," or the kinds of communicative events in which people engage in everyday life. These tasks require comprehending, producing, manipulating, or interacting in authentic language while attention is principally oriented to meaning rather than form (Nunan, 1989). Basic pair work and group work (Gaies, 1985; Doughty \& Pica,1986) and more structured cooperative learning formats (Johnson, Johnson, \& Holubec, 1986; Slavin, 1981, 1983, 19891990) are often used in task-based instruction. Task-based instruction, based on earlier concepts of Allwright and Prabhu, engages and involves learners personally in negotiating for meaning (Long \& Porter, 1985; Kumaravadivelu, 1991). Context is frequently embedded because tasks give many clues to meaning.

Task-based instruction can be used at all age levels, not just with adults, and at all proficiency levels. Task-based instruction is usually presented in one of two modes: through one- or two-way tasks (Doughty \& Pica, 1986). One-way tasks are those in which one person, the teacher or a single student, has information and shares it with other members of the class; but sometimes only the more confident, more linguistically competent student dominates the conversation. Two-way tasks -we might more accurately call them multi-way tasks-require the exchange of information among all participants, each of whom has some information not known but clearly needed by all the other participants to solve a problem. Twoway tasks tend to generate real communication by students of all proficiency levels.

Content in task-based instruction may be academic (as in a 
thematic, task-based unit on political structures), but it is not always of the usual academic sort. Non-traditional content is used as the basis for an "English through Video-Making" course for tertiary intensive ESL students, described by Talbott and Oxford (1990). In this course, the content to be learned was how to make a television program; in other words, the content itself consisted of the process of video-making-not a typical academic subject except in colleges of communication on university campuses. The course demonstrated that students who wrote, produced, directed, choreographed, and acted in their own television programs developed their communicative skills at a much more rapid pace than did students in regular classes focusing more clearly on "learning English." Non-traditional content was also used in a recent study by Lavine (forthcoming), who shows how language labs can be transformed into communication centers. The content in these centers is related to a hypothetical computerized dating service. Students participate in an entertaining series of communication tasks tied to computerized date-matching.

\section{Adjunct CB-ESL}

Adjunct CB-ESL is a specific instructional method focusing on linking instructors and curricula for language and content courses. For example, the ESL instructor might work closely with the psychology or biology instructor in providing language and content instruction in a way that optimizes learning in both areas simultaneously. The adjunct model differs from the theme-based model and the sheltered model in requiring participation of a mix of native and nonnative speakers in the content component (Brinton, Snow, \& Wesche, 1989). Native speakers of the language do not need to participate in the language component with the non-native speakers. Moreover, adjunct instruction is most appropriate for adults with academic or vocational goals (though other ages could participate if programs were arranged for them) whose proficiency level is high intermediate to advanced. No special subject matter knowledge is assumed for the students. Often the context is reduced in adjunct instruction due to the academic level and the subject area.

Snow and Brinton (1988) compared UCLA students using the adjunct model with a comparison group of students enrolled in a more traditional segregated-skill ESL program. Students in the adjunct class at the beginning had significantly lower ESL placement scores than the comparison group. Nevertheless, these students did as well as the comparison group on a content-based examination which required them to listen to a lecture and read an excerpt from a political science text, and then to use this information to complete short-answer 
questions and write an essay.

The fact that the initially-lower adjunct students did as well at the end as the traditional students, who at first scored higher, suggests that the adjunct students made greater gains overall. Snow and Brinton attribute their findings to the content-based language class, which exposed students to integrated language skills and to the types of academic tasks required for university study. In other words, the students in the adjunct class used the language in a normal, academic way, just as they would be expected to do in any university situation, while the comparison group used the language in a more artificial manner. Brinton, Snow, and Wesche (1989) also note that the adjunct language program had the benefit of a positive on-campus residential setting, academic and personal counseling services, forums, social programs, and tutoring services.

\section{Sheltered CB-ESL}

Sheltered CB-ESL is also a specific methodology as opposed to a more general approach. In sheltered CB-ESL, students learn the content through simplified English tailored to their language level. The sheltered model, according to Brinton, Snow, and Wesche (1989) is appropriate for all ages, but at the tertiary level it is best for intermediate to high intermediate ESL proficiency levels. These authors also state that the sheltered model should ideally be restricted to highly motivated learners pursuing academic or vocational goals related to the subject matter. In sheltered CB-ESL, the context is typically reduced due to the educational level and the subject area, although the language is simplified.

Starting with a course on an introduction to psychology, the University of Ottawa has used sheltered instruction extensively with the double goal of teaching subject matter and academic language skills (in French as a second language for English speakers and English as a second language for French speakers). The sheltered model extended to other content areas besides psychology.

Studies of this model at the University of Ottawa showed strong student gains in both subject matter and second language skills. These gains were equal to or better than those of comparison groups taking the course in their first language and students in regular French and ESL classes (Edwards, Wesche, Krashen, Clément, \& Kruidenier, 1984; Hauptmann, Wesche \& Ready, 1988). Brinton, Snow, and Wesche also point to evidence of program effectiveness in the very low attrition rates in the sheltered program at the University of Ottawa.

Unfortunately, budget cuts caused the University to cancel its sheltered lecture sections because of their comparatively low enroll- 
ments. A modified adjunct model is now used, but the University hopes to reinstate a fully sheltered course in psychology at a later date.

We have discussed characteristics of five approaches and methods associated with tertiary CB-ESL. We now turn to tertiary CB-ESL issues tied to specific subject fields.

\section{TERTIARY CB-ESL ISSUES RELATED TO INSTRUCTION IN SPECIFIC SUBJECT AREAS}

As might be expected, the different subject areas-mathematics, social studies, and science-raise varied instructional problems and issues in the context of tertiary CB-ESL. These three fields have been chosen because there has been more research done concerning these domains than concerning any others. Let us look at these three subject areas in turn.

\section{Tertiary CB-ESL Issues in Mathematics}

Language ability and mathematics achievement are highly correlated, according to research with tertiary students learning English as a second language. Duran (1980) found a strong positive correlation between reading comprehension ability of Puerto Rican college students and their performance on mathematical deduction problems in both English and Spanish. In fact the same patterns of correlation arose for both languages. Others (e.g., Cuevas, 1984; Cossio, 1978) have discovered similar results with students of various ages. Yet Dale and Cuevas (1987) point out that merely being able to "read" a text superficially does not guarantee the depth of conceptual, mathematical understanding necessary for actually solving mathematical problems. Mathematical thinking (thinking through problems and working symbolically) and metacognition (the ability to think about and evaluate the problem-solving process objectively) are both necessary for successful mathematics performance (Kessler, Quinn, \& Hayes, 1985). Content-based courses at the tertiary level are uniquely suited for developing mathematical thinking and metacognition, along with language skill. Many theorists of content-based language learning emphasize that language teachers should teach thinking skills and metacognition in the language classroom (see, e.g., O'Malley \& Chamot, 1991).

Crandall, Dale, Rhodes, and Spanos (1985) studied the mathematics-learning process among limited English proficient students at the college and high school level. They found that basic algebra students showed recurring errors in translations of the language of word problems into the equations these students used to solve them. In other words, the students repeatedly mistranslated the narrative 
statements into incorrect equations. The reason for this was that the students tended to duplicate the surface syntax of English in the original problem as they restated the problem into the algebraic format. In many instances, the surface syntax could not be directly translated into algebraic format in this way. For instance, The number $\boldsymbol{a}$ is five less than the number $\boldsymbol{b}$ was often transformed into $\boldsymbol{a}=5-\boldsymbol{b}$, instead of the correct phrasing: $a=b-5$.

Similar difficulties in syntax mistranslation were found among Hispanic engineering students in college algebra courses (Mestre, Gerace, \& Lockhead, 1982). These researchers noted that Hispanic students were much more likely than nonminority students to mistranslate word problems, and they were also more prone to slower reading speed and more missed problems on tests. Mestre (1984) suggests that more experience with speeded problem-solving and mathematical translation in a content-based mathematics/English course would enable these students to glean information and set up mathematical problems correctly.

The implication of these researchers was that in a content-based course linking language and mathematics, students need to be taught that the apparent linguistic syntax of mathematics is not the same as the underlying linguistic syntax, which must be reflected in the syntax of the mathematical symbols. A content-based mathematics/English course could clarify syntactic points, such as order of parts of the statement (cited above). Mestre (1984) specifically suggests that more experience with speeded problem-solving and mathematical translation in a content-based mathematics/English course would enable limited English proficient students to glean information and set up mathematical problems correctly.

Logical connectors such as if . . then, because, for example, either ... or, or consequently also pose syntactic problems for limited English proficient students learning mathematics. Dale and Cuevas (1987) note that younger students are likely to have more difficulties than older students due to cognitive developmental stages in the Piagetian sense, but it is probable that some tertiary students would still have some problems with some of the more complex logical connectors (e.g., such that, if and only if).

Tertiary students who are learning English and mathematics in a content-based course are likely to have some difficulties with the vocabulary of mathematics, unless they have already fully grasped the vocabulary (and concepts behind the vocabulary) in their own language (see Dale \& Cuevas, 1987 for mathematics vocabulary information and Oxford, 1990, for vocabulary learning strategies). In addition, these students might experience semantic difficulties in locating the key 
words in a problem statement (Dale \& Cuevas, 1987), unless they have already developed the language learning strategy of skimming for the main word or main idea (Oxford, 1990). Another semantic difficulty that often occurs in students who are beyond the beginning level is to expect a one-to-one correspondence between words and symbols; they carry over their earlier mathematics experience to situations in which such a one-to-one correspondence does not exist (Dale \& Cuevas, 1987). Content-based mathematics courses can assist students in overcoming the vocabulary-related and semantic problems, particularly if these courses emphasize the use of specific language learning strategies.

An additional problem often found among students who are learning mathematics through a new language is the type of discourse found in the textbook. Mathematics textbooks are known for their high density, high technicality, and high symbolism, leading to a slower reading rate and the need for repeated readings of even a very short passage (Bye, 1975). College-level and graduate textbooks in mathematics (and the sciences) are often egregiously bad in this respect. Native speakers of the language typically have difficulty with the discourse features of mathematics textbooks, but the problems are almost exponentially compounded for sécond language learners. Clearly, content-based mathematics/English courses could assist second language learners in developing their ability with the typical discourse of mathematics texts.

\section{Tertiary CB-ESL Issues in Social Studies}

Social studies instruction presents a different set of issues from those posed by mathematics instruction, particularly at the tertiary level. One problem with social studies is the level of cognition at which courses are taught. While Anderson, Hiebert, Scott, and Wilkenson (1984) state that social studies classes are an ideal place for developing both language skills (such as reading comprehension) and thinking skills, King, Fagan, Bratt, \& Baer (1987) assert that this opportunity is rarely exploited. Even at the tertiary level, social studies courses such as history or sociology sometimes consist of rote memorization of facts or lexical recognition of concepts or labels, rather than in-depth application, analysis, evaluation, or synthesis of important problems. Such lessons can be demotivating and boring to tertiary students, who have the capability of thinking at a higher stage of cognition.

More so than in the area of mathematics, the role of background knowledge and cultural values is crucial in social studies at the tertiary level. Students who are learning English for the first time are 
confronted with a set of expectations, namely that they should cope with their social studies classes by having (or immediately developing) the same background knowledge and cultural values as native English speakers. A content-based social studies/English class can help ESL learners develop the background knowledge that they need and more clearly and explicitly observe the cultural values of their new country, all in the context of learning the subject matter (King, Fagan, Bratt, \& Baer, 1987).

Although the recommendations of King et al. refer specifically to elementary and secondary content-based social studies/English classes, the same principles apply directly to tertiary instruction. For instance, curriculum development should include a variety of major concepts illustrated by different situations and settings, all related to the cognitive structures the students have already developed. The curriculum should be viewed as preparation for mainstream social studies classes rather than as a substitute for them, according to these authors; other researchers might disagree. As King et al. state, higherorder thinking skills should definitely be included in the content-based social studies/English curriculum, although the language might be simplified somewhat via "sheltered" social studies courses. Criterionbased instruments related to the objectives of the program are necessary. Multimedia teaching strategies, including training students to use improved learning and thinking strategies such as semantic webbing (also known as semantic maps or nets), are essential.

\section{Tertiary CB-ESL Issucs in Science}

Kessler and Quinn (1987), while describing elementary and secondary content-based instruction in science and English, offer some important principles that can be applied to tertiary science contentbased instruction. These writers assert that science poses serious terminology problems for ESL learners, and that vocabulary instruction in science must be fully contextualized rather than done in the form of disembodied lists. Hands-on activities are most valuable for development of scientific concepts and vocabulary.

Language learning, like science learning, involves risk-taking and experimentation (Kessler \& Quinn). Science offers an exceptionally rich source of potentially comprehensible input that enables ESL students to take appropriate risks. This input includes pictures, diagrams, objects, oral directions, written information, and paralinguistic and extralinguistic cues. Science thus provides the multimedia assistance that should, in fact, be accessible in any kind of language class, not just in content-based language classes. Scienceespecially the structured laboratory activity-also stimulates interaction 
among learners in the new language and can (if handled appropriately by the teacher) be highly motivating and nonthreatening.

Kessler and Quinn provide extensive examples of elementary and secondary content-based science classes that develop cognitive language ability (what Cummins calls CALP, as discussed above) in the science area. Unfortunately, no tertiary classes or programs are specifically mentioned, although Kessler and Quinn clearly state "the overall principles [of content-based science instruction for ESL students] are not age-dependent" and are therefore relevant to "the ... college or university science student."

\section{INSTRUCTIONAL IMPLICATIONS AND RESEARCH ISSUES}

This article has explored some of the issues in tertiary content-based ESL instruction using an international perspective. We have seen that tertiary CB-ESL is a growing, flourishing phenomenon that has taken hold in the U.K., the U.S., Canada, and elsewhere. Tertiary CB-ESL includes several specific instructional models which are being tested in many settings; it also includes some broader instructional perspectives. From the comments above, the following instructional implications and research issues can be raised:

1. Tertiary CB-ESL offers a useful way to link the various language skills (reading, speaking, etc.) in meaningful communication. It moves away from the study of a language as merely a set of structures or symbols and toward the acquisition of communicative skills related to content.

Related research issues include: Content and Language Integration: To what degree is grammar important in various kinds of tertiary $\mathrm{CB}$ ESL, and how can grammatical competence be woven into the content? Likewise, how should other aspects of communicative competence (strategic, discourse, sociolinguistic) be addressed through content in tertiary CB-ESL? Students: Given that certain students will prefer one type of tertiary CB-ESL over other types, how can these preferences and needs be most easily determined, and how can students be channeled into the most appropriate learning situations? Course Structure: Since most institutions have limited resources and need to focus those resources carefully, which of the course structures is most valuable for the most people? Context Reduced or Embedded: To what degree should context be embedded, and does this richness of context give an unrealistic advantage to students who will have to face context-reduced classrooms later on? When are students ready to have the communication context reduced, as in more typical academic courses? What continuing supports are necessary for ESL students? 2. ESP is a general approach that teaches the use of English for 
specific situations and particular needs. This perspective is becoming increasingly popular in many countries. It is often highly motivating.

Related research issues are: Content and Language Integration: To what degree should ESP programs focus on language aspects vs. the specific content? How can language teachers become comfortable with an unfamiliar content base? Students: Are there any techniques that would be the most relevant or useful for teaching ESP for students from very different disciplines? Does this depend largely on the cultural backgrounds, interests, age, and sex of the learners? Course Structure: Do different contexts require different types of course structures? Context Reduced or Embedded: How can context richness be maintained in ESP classes?

3. Theme-based CB-ESL is highly adaptable with heterogeneous groups of learners of multiple proficiency levels. This model can easily be used in tertiary ESL programs and is now widely applied in both foreign and second language situations.

Related research questions include: Content and Language Integration: How should the teacher or curriculum designer decide the most relevant themes for heterogeneous groups, and how should language aspects like grammar and vocabulary be integrated into thematic instruction? Students: What happens if one or two students simply are less interested than others in the theme at hand? What kinds of adaptations can be made for individuals who wish to go into a particular theme with greater depth than other people? How can the same theme be used for students at different proficiency levels? Course Structure: Assuming that themes are the basis of the course structure, how many themes should be included during one course? Are broader or narrower themes more useful and more motivating? Context Reduced or Embedded: Theme-based learning often has highly embedded context; is this appropriate preparation for students who are going into different situations later on?

4. Task-based $C B$-ESL is useful with students of all proficiency levels, as long as the tasks are authentic, motivating, and communicative. This instructional mode elicits large amounts of interaction among participants and is increasingly used in tertiary programs.

Related research questions include: Content and Language Integration: How can teachers make sure that tasks are authentic, motivating, and communicative while maintaining at least some emphasis on structures of language? Students: How can tasks best be used with students of mixed ability? To what degree should student groupings be made according to learning style preferences? Course Structure: Tasks ordinarily involve more than one student, thus raising the question, what is the role of peer tutoring in a task-based format? 
Under what circumstances are one-way tasks useful, and when should two-way tasks be used? Context Reduced or Embedded: Do tasks always need to provide rich context, or should some tasks be more abstract and context-reduced?

5. Adjunct $C B-E S L$ appears to succeed best when it involves participation by high intermediate to advanced ESL learners and by native English speakers in the content course. It also requires collaboration by the content teacher and the language teacher in planning and delivering courses.

Related research issues are: Content and Language Integration: Content and language are integrated through logistical and intellectual coordination of various kinds; to what extent does this coordination make the adjunct model difficult to use in most tertiary settings? Students: Do native English speakers feel that the courses are in any way watered down, or do they feel that they get the same quality and intensity of content learning as they would in courses that did not involve non-native speakers? How do non-native speakers feel when they are asked to work with (and sometimes compete with) native speakers in activities? Course Structure: What kind of institutional supports are necessary for this highly coordinated course structure to take place? Context Reduced or Embedded: To what degree should embedded context be retained as classes become more cognitively demanding?

6. Sheltered $C B-E S L$ is a particular instructional model involving simplified English for the teaching of content. Investigators suggest that this model is useful for intermediate proficiency students who are highly interested in the particular content (social science, economics, and so on).

Related research issues include: Content and Language Integration: To what degree should the language be simplified while complex content is used? Students: How can students know if they might be interested in the content if they have not yet been exposed to this subject in their own language? Is it not true that people often develop motivation based on personal involvement in academic courses? Course Structure: Is there any way to combine sheltered CB-ESL with other modes of tertiary CB-ESL, especially theme-based? Could a sheltered adjunct CB-ESL course be created that would accommodate students with lower language proficiency levels? Context Reduced or Embedded: What is the best degree of contextual assistance for students of different ages and backgrounds?

7. It is clear that different subject areas, such as social studies, mathematics, and science, have a variety of instructional problems associated with tertiary CB-ESL. Each one deserves singular attention. 
Related research issues include: Content and Language Integration: How can the perplexing syntactic and semantic difficulties of mathematics, science, and social studies be best addressed by tertiary CBESL? Students: How can differences in students' background knowledge and interests be overcome and/or optimally used in any subject area of CB-ESL instruction? Course Structure: To what degree should course structures differ by discipline? Context Reduced or Embedded: How can vocabulary and concepts in these disciplines be taught in a hands-on, high-context fashion within tertiary CB-ESL, thus making the subjects come alive for many more students? At what stage should context be reduced?

Clearly, we have come a long way in our understanding and use of tertiary CB-ESL in the last two decades. Just as obviously, we have a long way to go in knowing how to optimize the approaches and methods that cluster under the banner of tertiary CB-ESL. Researchers should investigate the issues raised above. Teachers should join with researchers in identifying classroom practices that work effectively and those that do not-and under what circumstances and with which kinds of students.

Linking tertiary CB-ESL with an underlying, solid theory of adult language acquisition is a very important task. This is the least discussed, but perhaps the most significant, issue of all. The proliferation of CB-ESL practice has moved far more quickly than has the elaboration of a fundamental theory of adult language development to undergird CB-ESL. Recent books like those of Larsen-Freeman and Long (1991), Labarca and Bailey (1990), Scarcella and Oxford (1992), and Van Patten and Lee (1990) give us reason to hope for a unification between theory and practice in adult ESL, even though not all of these volumes highlight CB-ESL to the extent they might have. In the next decade, given the growing awareness of the need for explanatory theory in ESL, we can expect to see theory and practice come closer together in the area of tertiary CB-ESL.

\section{ACKNOWLEDGMENTS}

Some of the research synthesis shown here was funded through a contract to the Center for Applied Linguistics from the U.S. Office of Bilingual Education and Minority Languages Affairs. Thanks go to Marguerite Ann Snow, Robin Scarcella, JoAnn Crandall, Sheena Gardner, Janet Carroll, and three anonymous reviewers for their helpful comments on different versions of this material. 


\section{THE AUTHOR}

Rebecca L. Oxford, Ph.D., is a tenured Professor of Language Education at the University of Alabama. She directs the MA-TESOL Program, the Foreign Language Education Program, and the Japanese Satellite Program. These programs span three colleges at the university: Arts \& Science, Education, and Communications. She is the head of the faculty in the College of Education. Her consulting around the world centers on language learning styles, and strategies, teaching methods, motivation, and computer-assisted instruction. She is also co-editor of the TAPESTRY PROGRAM for ESL/EFL and has written many books and articles in the language field.

\section{REFERENCES}

Anderson, R., Hiebert, E., Scott, J., \& Wilkenson, S. (1984). Becoming a nation of readers: The report on the Commission on Reading. Washington, DC: Department of Education.

Bridgeman, B. \& Carlson, S. (1983). Stuvey of academic writing tasks required of graduate and umdergraduate foreign students. TOEFL Research Report No. 15. Princeton, NJ: Educational Testing Service.

Brinton, D. M., Snow, M. A., \& Wesche, M. B. (1989). Content-based second language instmuction. New York: Newbury House / Harper \& Row.

Bye, M. P. (1975). Reading in math and cognitive development. Unpublished master's thesis.

Cantoni-Harvey, G. (1987). Content-area language instruction: Approaches and strategies. Reading, MA: Addison-Wesley.

Chamot. A. U. (1983). Toward a functional ESL curriculum in the elementary school. TESOL Quanerly, 17, 459-471.

Collier, V. (1989). How long? A synthesis of research on academic achievement in second language. TESOL Quarterly, 23(3), 509-531.

Cossio, M. G. (1978). The effects of language on mathematics placement scores in metropolitan areas. Dissertation Abstracts International, 38, 4002A-4003A.

Crandall, J., Dale, T. C., Rhodes, N.. \& Spanos, G. (1985). The langnage of mathematics: The English barrier. Paper presented at the Delaware Symposium on Language Studies, University of Delaware, Newark, DE.

Cuevas, G. K. (1984). Mathematics learning in English as a second language. Joumal for Research in Mathematics Education, 15, 134-155.

Cummins, J. (1979). Linguistic interdependence and the educational development of bilingual chldren. Review of Educational Research, 49, 222-251.

Cummins, J. (1981). The role of primary language in promoting educational success for language minority students. In Schooling and language minority students: A theoretical framework. Los Angeles: Evaluation, Dissemination, and Assessment Center.

Cummins, J. (1982). Tests, achievement, and bicultural ambivalence. Rosslyn, VA: Clearinghouse on Bilingual Education.

Cummins, J. (1984). Bilingualism and special education: Issues in assessment and. pedagogy. Clevedon, UK: Multilingual Matters.

Dale, T. C. \& Cuevas, G. J. (1987). Integrating language and mathematics learning. In J. Crandall (Ed.), ESL through content-area instriction (pp. 9-54). Englewood Cliffs, NJ: Prentice Hall. 
Doughty, C. \& Pica, T. (1986). "Information gap" tasks: Do they facilitate second language acquisition? TESOL Quarterly, 20(2), 305-24.

Duran, R. P. (1980). Bilinguals' skills in solving logical reasoning problems. Unpublished master's thesis.

Edwards, H. P., Wesche, M. B., Krashen, S., Clement, R., \& Kruidenier, B. (1984). Second language acquisition through subject-matter learning: A study of sleltered psychology classes at the University of Ottawa. Canadian Modern Language Review, 41, 268-82.

Eskey, D., Kraft, C., \& Alvin, M. C. (1984). Structuring a content-based syllabus. Paper presented at the annual meeting of Teachers of English to Speakers of Other Languages, Houston.

Fein, D., \& Baldwin, R. (1986). Content-based curriculum design in advanced levels of an ESL program. English for Foreign Students in English-Speaking Countries-Interest Section Newsletter, 4(1), 1-3.

Gaies, S. (1985). Peer involvement in langtage leaming. New York: Harcourt Brace Jovanovich.

Giauque, G. (1987). Teaching for content in a skills course: Greek mythology in French. Foreign Language Annals, 20 (6), 565-569.

Hauptmann, P. C., Wesche, M. B., \& Ready, P. (1988). Second language acquisition through subject matter learning: A follow-up study at the University of Ottawa. Language Leaming, 38(3), 439-482.

Hutchinson, T. \& Waters, A. (1987). English for specific purposes: A learner centred approach. Cambridge: Cambridge University Press.

Johns, A. (1981). Necessary English: A different story. TESOL Quarterly, 15(1),51-57.

Johnson, D. W., Johnson, R., \& Holubec, E. (Eds.) (1986). Circles of learning: Cooperation in the classroom (rev. ed.). Edina, MN: Interaction Book Co.

Kessler. C. \& Quinn, M. E. (1987). ESL and science learning. In J. Crandall (Ed.), ESL through content-area instuction (pp. 55-88). Englewood Cliffs, NJ: Prentice Hall.

Kessler. C.. Quinn, M. E.. \& Hayes, C. W. (1990). Processing mathematics in a second language: Problems for LEP children. In A. Labarca \& L.M. Bailey (Eds.), Issues in L2: Theon as practice/practice as theony. Norwood, NJ: Ablex.

King, M., Fagan. B.. Bratt. T., \& Bacr, R. (1987). ESL and social studies instruction. In J. Crandall (Ed.), ESL through contcht-arca instruction (pp. 89-120). Englewood Cliffs, NJ: Prentice Hall.

Kroll, B. (1979). A survey of the writing needs of foreign and American college freshmen. ELT Joumal, 33(3), 219-26.

Kumaravadivelu, B. (1991). Language learning tasks: Teacher intention and learner interpretation. ELT Joumal, 45(2), 98-107.

Labarca, A. \& Bailey, L. M. (Eds.). (1990). Issues in L2: Theory as practice / practice as theon. Norwood, NJ: Ablex.

Latayette, R. C. \& Buscaglia, M. (1985). Students learn language via a civilization course: A comparison of second language classroom environments. Studies in Second. Language Acquisition, 7, 323-342.

Larsen-Freeman. D. \& Long, M. (1991). An introduction to second language acquisition research. New York: Longman.

Lavine, R. Z. (in press). Task-based language laboratory activities. Hispania.

Long, M. (1985). Input and second language acquisition theory. In S. Gass \& C. Madden (Eds.), Input and second language acquisition. Rowley, MA: Newbury House. 
Long, M. \& Porter, P. A. (1985). Group work, interlanguage talk, and second language acquisition. TESOL Quarterly, 12(2), 207-228.

Mestre, J. P. (1984). The problem with problems: Hispanic students and math. Bilingual Joumal, Fall, 15-20.

Mestre, J. P., Gerace, W. J., \& Lockhead, J. (1982). The interdependence of language and translational math skills among bilingual Hispanic engineering students. Joumal of Research in Science Teaching, 19, 399-410.

Mohan, B. (1986). Language and content. Reading, MA: Addison-Wesley.

Mohan, B. (1990). LEP students and the integration of language and content: Knowledge structures and tasks. Paper presented at the National Symposium on Limited English Proficient (LEP) Students Research Issues, Office of Bilingual Education and Minority Languages Affairs, Washington, DC.

Nunan, D. (1989). Designing tasks for the communicative classroom. Cambridge: Cambridge University Press.

O'Malley, J. M. \& Chamot, A. U. (1991). Leaming strategies in second language acquisition. Cambridge: Cambridge University Press.

Ostler, S. (1980). A survey of academic needs for advanced ESL. TESOL Quarterly, $14(4), 489-502$.

Oxford, R. L. (1990). Language leaming strategies: What even teacher should know. New York: Newbury House / Harper \& Row.

Oxford, R. L., Lee, D. C., Snow, M. A., \& Scarcella, R. C. (in progress). Integrating the language skills: A study of intensive university ESL programs.

Reid, J. (1984). TTT review: Teachers, texts, and technology in EFL/ESL training. Fort Collins: Colorado State University.

Richards, J. C. \& Hurley, D. (1990). Language and content: Approaches to curriculum alignment. In J. C. Richards (Ed.), The language teaching matrix. Cambridge: Cambridge University Press.

Richards, J. C. \& Rodgers. T. (1986). Approaches, methods, and techniques in language teaching. Cambridge: Cambridge University Press.

Santos, T. (1988). Professors' reactions to the academic writing of nonnative-speaking students. TESOL Quarterly, 22, 69-90.

Scarcella, R. C. \& Oxford, R. L. (1992). The tapestry of language leaming: The individual in the communicative classroom. Boston: Heinle \& Heinle.

Secada, W. G. \& Carey, D. A. (1990). Teaching mathematics with understanding to limited English proficient students. Urban Diversity Series Number 101.

Short, D., Crandall, J., \& Christian, D. (1989). How to integrate language and content instruction: A training manual. Washington, DC: Center for Applied Linguistics. (ERIC No. ED 305824 )

Slavin, R. (1981). Synthesis of research on cooperative learning. Educational Leadership, 655-60.

Slavin, R. (1983). Cooperative leaming. New York: Longman.

Slavin, R. (Dec. 1989 - Jan. 1990). Research on cooperative learning: Consensus and controversy. Educational Leadership, 47(4), 52-55.

Snow, M. A. \& Brinton, D. M. (1988). Content-based language instruction: Investigating the effectiveness of the adjunct model. TESOL Quarterly, 22:553-74.

Snow, M. A. \& Brinton, D. M. (1991). The cross-curricular revolution in EAP: Recognizing the role of content in language instruction. Paper presented at the annual meeting of Teachers of English to Speakers of Other Languages, New York.

Snow, M. A., Met, M., \& Genesee, F. (1989). A conceptual framework for the integration of language and content in second/foreign language instruction. TESOL Quarterly, 23, 201-17. 
Spack, R. (1988). Initiating ESL students into the academic discourse community: How far should we go? TESOL Quarterly, 22(1), 29-51.

Spanos, G. (1989). On the integration of language and content. Antual Review of Applied Linguistics, 10, 227-40.

Swales, J. (1985). Episodes in ESP. Oxford: Pergamon.

Talbott, V., \& Oxford. R. L. (1991). Creating a video variety show: Student-generated simulations. Simulation/Games for Lcaming, 20(4), 378-97.

Van Patten, B. \& Lee, J. (1990). Second language acquisition-foreign language learning. Clevedon, Avon: Multilingual Matters. 